\title{
Restoration ecology and conservation biology
}

\author{
Truman P. Young \\ Department of Environmental Horticulture, University of California, Davis, CA 95616, USA
}

Received 10 November 1998; received in revised form 10 March 1999; accepted 24 March 1999

\begin{abstract}
Restoration ecology is undergoing rapid growth as an academic discipline, similar to that experienced by conservation biology over the last 15 years. Restoration ecology and conservation biology share many underlying biodiversity goals, but differ in striking ways. Using data from published literature in these two fields, I document that conservation biology has been more zoological, more descriptive and theoretical, and more focused on population and genetic studies than restoration ecology, which has been more botanical, more experimental, and more focused on population, community and ecosystem studies. I also use documented trends in population, land use, and biodiversity awareness to suggest that in the future ecological restoration will play an increasing role in biodiversity conservation. The conservation mind set is one of loss on a relatively short time horizon, whereas the restoration mind set is one of long-term recovery. I suggest that a restoration mind set can provide useful insights into problems of conservation today, illustrated with examples examining edge effects and integrated conservation and development projects. (C) 1999 Elsevier Science Ltd. All rights reserved.
\end{abstract}

Keywords: Restoration; Conservation; Controlled experiments; Edge effects; ICDP

\section{Introduction and apologia}

Restore v. to make almost as good as new; to give back. (two different New York Times Crosswords)

As we enter the new century, restoration ecology is undergoing dramatic growth as an academic discipline (Fig. 1a). A decade ago, the field of conservation biology experienced similar explosive growth. Both of these "new" academic fields build upon many years of earlier work by applied scientists in wildlife biology, forest and range management, and even horticulture and landscape architecture. Each found its renaissance through the attentions of academic biologists, whose research interests were molded to fit the new and critical needs of biodiversity conservation and restoration (Soule 1986; Jordan et al., 1987). Although there are many parallels and shared goals between conservation biology and restoration ecology, there are also important differences. In this overview, I will (a) quantify some of the differences between conservation biology and restoration ecology, both operationally and philosophically,

E-mail address: tpyoung@ucdavis.edu (T.P. Young) (b) suggest a long-term ascendancy of restoration ecology, and (c) give examples of how a restoration mind set can illuminate conservation today.

Any discussion of ecological restoration in the context of conservation biology must begin with two resounding caveats:

1. Although restoration can enhance conservation efforts, restoration is always a poor second to the preservation of original habitats.

2. The use of ex situ 'restoration' (mitigation) as an equal replacement for habitat and population destruction or degradation ('take') is at best often unsupported by hard evidence, and is at worst an irresponsible degradative force in its own right.

However, the fact that ecological restoration can be misused to the detriment of biodiversity conservation need not blind us to its tremendous potential to achieve laudable conservation goals when implemented appropriately (Falk et al., 1996; Zedler, 1996a,b).

Although this paper will suggest a long-term ascendancy of restoration ecology, it is not my intention to suggest this implies that the current biodiversity crisis is anything less than the most important challenge of our generation, nor to suggest that the potential of ecological 
restoration somehow gets us 'off the hook' in our obligation to minimize the current extinction spasm through the aggressive application of political pressure, human and financial resources, and modern principles of conservation biology.

Also, I do not wish to suggest a simple dichotomy between restoration ecology and conservation biology. Indeed, I consider restoration to be a subset of conservation. The comparison I make below is between conservation biology as it is practised in the 1990s and the newly emerging academic field of restoration ecology.

\subsection{Conservation, the science of habitat and biodiversity loss: stemming the flow}

In his insightful paper, 'Directions in conservation biology', Graehme Caughley (1994) identified two major paradigms in conservation biology. The declining population paradigm emphasizes the forces that cause populations to decline, and focuses operationally on ways to lessen those forces and reverse declines. The declining population paradigm in many ways anticipates restoration ecology, and has been the primary approach of wildlife and fisheries professionals who for many decades were at the forefront of what we now call
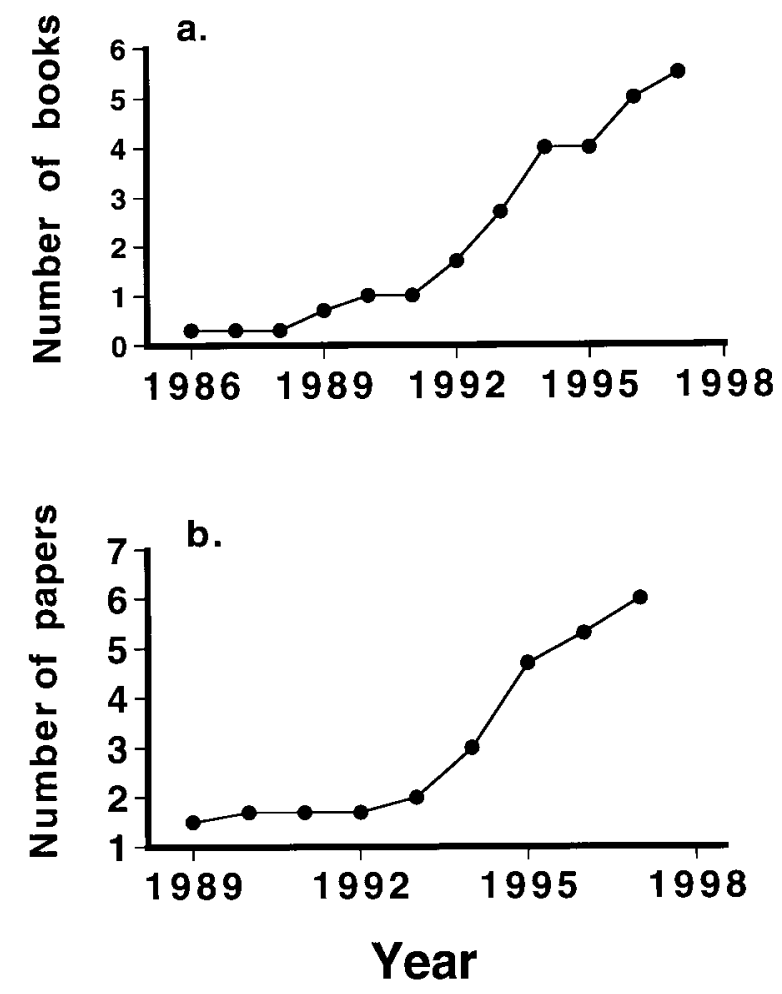

Fig. 1. (a) Three-year running mean of the number of books appearing in a key word search ('restoration ecology') of the University of California Melvyl ${ }^{\complement}$ library database, 1986-1998. (b) Three-year running mean of the number of papers with the title words 'land abandon\#' appearing in the Current Contents ${ }^{\odot}$ journal database for the years 1989-1998. \# is a truncation symbol. conservation biology. The small population paradigm emphasizes the unique risks of populations that have already been driven to dangerously small sizes, and focuses operationally on means to maintain population viability and minimize extinction in small populations. The small population paradigm has been the emphasis of the new generation of academic conservation biologists. Were I to add an additional (overarching) theme to these two, it would be that of fragmentation: fragmented populations and fragmented landscapes (Harris, 1984; Quammen, 1996; Laurance and Bierregaard, 1997; Schwartz 1997).

\subsection{Restoration, the science of habitat and biodiversity recovery}

Restoration ecology has at its core the assumption that many degradative forces are temporary, and that some proportion of habitat loss and population decline is recoverable. Of course, extinctions are forever and many habitat losses are not likely to be recovered. Such losses are increasingly preventable and inexcusable. Conservation biology deserves center stage as it seeks to minimize these permanent losses. Restoration ecology, thus far playing a secondary role, seeks to repair what can be repaired, and to ensure the future fate of surviving habitats and populations, regardless of whether they were previously threatened.

\section{A statistical comparison of conservation biology and restoration ecology}

There are several ways in which conservation biology and restoration ecology differ, at least in their current forms (Table 1). Some are due to historical biases; others are more deeply imbedded. These differences can be quantified. I examined all issues published in the journals 'Conservation Biology', 'Biological Conservation',

Table 1

Conservation biology and restoration ecology constrasted

\begin{tabular}{lll}
\hline Trait & Conservation biology & Restoration ecology \\
\hline Mind set & $\begin{array}{c}\text { (Threats of) } \\
\text { permanent losses } \\
\text { Genetic, population }\end{array}$ & $\begin{array}{c}\text { Long-term } \\
\text { recovery } \\
\text { Community, } \\
\text { ecosystem } \\
\text { organizational } \\
\text { levels }\end{array}$ \\
$\begin{array}{c}\text { Dominant } \\
\text { taxon }\end{array}$ & Vertebrate animals & Plants \\
$\begin{array}{c}\text { Dominant } \\
\text { conceptual } \\
\text { theme }\end{array}$ & $\begin{array}{c}\text { Population viability } \\
\text { and dynamics }\end{array}$ & $\begin{array}{c}\text { Succession and } \\
\text { assembly }\end{array}$ \\
$\begin{array}{c}\text { Dominant } \\
\text { mode of } \\
\text { inquiry }\end{array}$ & Decriptive and modeling & Experimental \\
\hline
\end{tabular}


'Restoration Ecology', and 'Restoration and Management Notes' for the last three years (1996-1998). Each research article was characterized with respect to organizational approach, focal taxa, mode of inquiry, and geographic region (Table 2).

\subsection{Organizational level}

In the journal survey, genetic/ecophysiological/population approaches out-numbered community/ecosystem/ landscape approaches by more than two to one in the conservation journals, whereas the latter outnumbered the former by $50 \%$ in the restoration biology journals $\left(X^{2}=6\right.$, d.f. $\left.=3, p<0.001\right)$ (Table 2$)$.

Conservation biology has been rooted in population biology. This is true both of historical wildlife management and the emergence of conservation biology as an academic discipline. Both conservation genetics and viability analyses are essentially population biology. Note that the common word in Caughley's two paradigms is 'population'. Most conservationists understand that this emphasis is at least partly misplaced and would agree that habitat loss is the greatest threat to biodiversity today. Nonetheless, it is populations of endangered species that have attracted the most scientific, public, and legislative interest. In addition, many populations are (a) superficially amenable to explicit modeling, and (b) subject to (genetic) laboratory and short-term field studies, both of which have encouraged an emphasis in the scientific literature in favor of population approaches to conservation. And of course, extinction occurs one population at a time.

In contrast, recent research in restoration ecology is more broadly rooted in community and ecosystem

Table 2

Analysis of four journals devoted to conservation biology and ecological restoration. BC, Biological Conservation; CB, Conservation Biology; RE, Restoration Ecology; RMN, Restoration and Management Notes ${ }^{\mathrm{a}}$

\begin{tabular}{|c|c|c|c|c|c|c|}
\hline \multirow{2}{*}{$\frac{\text { Topic }}{\text { Journal }}$} & \multicolumn{3}{|c|}{ Conservation biology } & \multicolumn{3}{|c|}{ Restoration ecology } \\
\hline & $\mathrm{BC}$ & $\mathrm{CB}$ & Total & RE & $\mathrm{RMN}$ & Total \\
\hline \multicolumn{7}{|l|}{ Organizational level } \\
\hline Genetic/molecular & 19 & 63 & $82(12 \%)$ & 4 & 0 & $4(2 \%)$ \\
\hline Population & 218 & 172 & $390(57 \%)$ & 37 & 34 & $71(38 \%)$ \\
\hline Community & 80 & 43 & $123(18 \%)$ & 44 & 35 & $79(42 \%)$ \\
\hline Ecosystem/landscape & 44 & 42 & $86(13 \%)$ & 31 & 4 & $35(18 \%)$ \\
\hline \multicolumn{7}{|l|}{ Target taxon } \\
\hline Plants & 103 & 70 & $173(26 \%)$ & 74 & 72 & $146(72 \%)$ \\
\hline Animals & 244 & 236 & $480(72 \%)$ & 24 & 8 & $31(16 \%)$ \\
\hline Other kingdoms & 3 & 2 & $5(0.7 \%)$ & 5 & 0 & $5(2.5 \%)$ \\
\hline (Soil and water) & 9 & 2 & $11(2 \%)$ & 10 & 9 & $19(9 \%)$ \\
\hline \multicolumn{7}{|l|}{ Mode of inquiry } \\
\hline Controlled experiments & 24 & 16 & $40(6 \%)$ & 44 & 22 & $66(34 \%)$ \\
\hline Uncontrolled experiments & 40 & 41 & $81(12 \%)$ & 29 & 37 & $66(34 \%)$ \\
\hline Descriptive & 227 & 194 & $421(64 \%)$ & 25 & 17 & $42(22 \%)$ \\
\hline Theoretical/modeling & 32 & 52 & $84(13 \%)$ & 5 & 3 & $8(4 \%)$ \\
\hline Reviews & 22 & 14 & $36(5 \%)$ & 9 & 1 & $10(5 \%)$ \\
\hline \multicolumn{7}{|l|}{ Geographical region } \\
\hline \multicolumn{7}{|l|}{ Temperate, Boreal, and Polar } \\
\hline US and Canada (less Arctic) & 45 & 136 & 181 & 67 & 87 & 154 \\
\hline Europe & 123 & 22 & 145 & 11 & 2 & 13 \\
\hline Australia, New Zealand & 59 & 19 & 78 & 13 & 1 & 14 \\
\hline Temperate and Boreal Asia & 21 & 7 & 28 & 2 & 0 & 2 \\
\hline Other temperate (Africa and South Africa) & 26 & 20 & 46 & 2 & 0 & 2 \\
\hline Polar & 3 & 0 & 3 & 1 & 0 & 1 \\
\hline Total & 277 & 204 & $481(77 \%)$ & 96 & 90 & $186(96 \%)$ \\
\hline \multicolumn{7}{|l|}{ Subtropical and tropical } \\
\hline Americas & 21 & 35 & 56 & 4 & 3 & 7 \\
\hline Africa & 20 & 28 & 48 & 0 & 0 & 0 \\
\hline Asia & 12 & 19 & 31 & 0 & 0 & 0 \\
\hline Other & 5 & 2 & 7 & 0 & 0 & 0 \\
\hline Total & 58 & 84 & $142(23 \%)$ & 4 & 3 & $7(3.6 \%)$ \\
\hline
\end{tabular}

a Journal dates surveyed from January 1996 to October 1998. Numbers represent the numbers of articles found that had the targeted characteristics; percentages are in parentheses. Multiple entries per article within topic classes were allowed, and some articles were not attributable (e.g. to a particular geographical area). 'Population' also includes distributional, behavioral and ecophysiological studies (autecology). 'Uncontrolled experiments' are assessments of uncontrolled or unreplicated manipulations by humans, as well as natural experiments. 
ecology as well as population ecology (Table 2). Clearly, one cannot restore individual bits of biodiversity unless appropriate habitat (and soil) exist. There are of course population restoration projects that overlay functional ecosystems, and many of these lie at the interface between conservation and restoration (Bowles and Whelan 1994, and see below). Nonetheless, it is in the restoration of complex communities that restoration ecology finds its greatest challenges and opportunities, and its fullest expression.

\subsection{Dominant focal taxa}

The journal survey also revealed that conservation biology has been far more zoological (by nearly 3 to 1 ), and restoration ecology has been far more botanical (by more than 4 to 1 , see Table $2, X^{2}=207$, d.f. $=1$, $p<0.001)$. These biases were less in 'Biological Conservation' and in 'Restoration Ecology' than in 'Conservation Biology' and 'Restoration and Management Notes'. Articles in the restoration ecology journals were also more than three times as likely to be directed toward other kingdoms (soil bacteria and fungi) than were articles in conservation journals, although this was not statistically significant (Table $2, X^{2}=2.73$, d.f. $=1, p<0.10$ ).

The zoological emphasis in conservation biology is rooted more in history than in genuine need. Several factors combine to create this bias: decades of wildlife and fisheries interest in conservation, the early involvement of zoos, and the zoological bias implicit in our own taxonomic position (as expressed in public interest, nature films, endangered species listings, and whaling and ivory bans that are unaccompanied by bans on trade in tropical hardwood and old growth timber). A more detailed analysis of conservation biology articles suggests that among animal studies, there is a bias toward vertebrates as target taxa, in particular birds and mammals (invertebrates, 14\%; fishes, $8 \%$, amphibians, $3 \%$, reptiles, $9 \%$, birds, $34 \%$, mammals, $30 \%$ ). This parallels a similar bias in funding by conservation organizations, but not in the public opinion of species values, which is more evenly distributed among taxa, including plants (Czech et al., 1998).

Restoration ecology has been primarily a botanical science, and this is likely to continue. There has been criticism of this emphasis (Morrison, 1998) and an apologia (Allen, 1998), but I suggest that there is little need to be apologetic. We typically define ecosystems by their botanical components, e.g. oak-hickory forest, tall grass prairie. Plants comprise the vast majority of all terrestrial ecosystems' biomass, and anchor the base of trophic pyramids. Ecological restoration is justly botanically biased. For similar reasons, restoration ecology has a stronger soils component than conservation biology. Most restoration projects concentrate on establishing a basic suite of plant species, and often (less than ideally) let the animals and 'minor' plant species fend for themselves (Dobson et al., 1997a,b).

Nonetheless, restoration ecology could include more zoological science. The restoration of species of all taxa is an important restoration activity (Bowles and Whelan, 1994; Allen, 1998), and many restoration and mitigation projects have as their underlying objective the reestablishment of an animal population (Strum and Southwick, 1986; Kleiman et al., 1991). Most restoration projects, even when they are primarily botanical, would benefit from more explicit zoological consideration (Morrison, 1995; Neal, 1998). Zoological studies can be directly supportive of the botanical aspect of restoration when grazers, seed dispersers, and pollinators are central to the success of restoration efforts. Although less bias against zoological papers may be appropriate, it is likely that ecological restoration will continue to be primarily a botanical science, at least in terrestrial ecosystems.

\subsection{Mode of inquiry}

Controlled, replicated, manipulative experiments are considered a hallmark of good science, and they are increasingly the standard in ecology. In many conservation research projects, however, they are difficult to carry out, especially in the context of rare or threatened species. This is somewhat less the case in wildlife management, the antecedent for conservation biology. We are still in the early stages of discovering and quantifying what the problems are in biodiversity conservation, a process that is largely descriptive. One way that conservation biology has sought alternative rigor is through theoretical modeling of populations and gene pools (With, 1997), an approach less explored by restoration ecologists. Research in conservation biology is, therefore, more often descriptive and theoretical.

In contrast, ecological restoration is by definition a manipulative activity, and the majority of research is explicitly experimental. Again, the journal survey supports these differences. Articles in restoration ecology were more than five times as likely to include controlled, replicated experiments as were articles in conservation biology ( 34 vs $6 \%$, Table $2, X^{2}=210$, d.f. $=3, p<0.001$ ). Perhaps tellingly, botanical articles in conservation journals were more than three times as likely to include controlled, replicated experiments as were zoological articles (10 vs $3 \%)$.

The 'uncontrolled experiments' in conservation journals were mostly taking as much statistical advantage as possible of situations that were largely beyond the control of the researcher. In contrast, many of the 'uncontrolled experiments' reported in the restoration journals were in fact controlled manipulations by the researcher, but without replication. Too often, we lose opportunities to turn the experiments of restoration projects into more powerful scientific research (Michener, 1997). 


\subsection{Geographical region}

Although all four journals had a strong temperate (U.S. and European) bias, articles in the conservation biology journals were six times more likely to address tropical biomes than those in restoration ecology journals (23 vs $3.6 \%, X^{2}=36$, d.f. $=1, p<0.001$, Table 2 ). Conservation biology rightly recognizes that the biodiversity crisis is most profound in the tropics, and makes conscious efforts to report tropical research. In contrast, the paucity of tropical research by restoration ecologists represents a large void, and opportunity (see Parrotta and Turnbull, 1997; Lugo, 1998). Both of the surveyed restoration journals are published in the United States, and are even more parochial, with fully $79 \%$ of their articles referent to temperate North America, and all seven of their tropical papers from the Americas.

\subsection{Conceptual bases}

There has been considerable energy expended in defining the conceptual bases for conservation biology and restoration ecology (Hobbs and Norton, 1996; With, 1997; Allen et al., 1997). While this is a laudable activity, it also reflects our roots as academics who honor basic over applied research. I think we need to clearly distinguish between the genuine value of having deep conceptual roots, and the reality that we have a monumental operational task ahead of us in which huge (and intellectually challenging) research strides have been made and will continue to be made that are referent to these conceptual bases, but need not test them directly. A more balanced approach in which applied research is a full partner of research into the conceptual basis of problems is pursued at the United States Department of Agriculture, National Institutes of Health, and Environmental Protection Agency. A similar balance is reflected in journal articles and actual research by both conservation biologists and restoration ecologists, but only sporadically in the funding decisions of NSF or the committee rooms of doctoral and masters candidates.

On average, the conceptual bases of conservation biology have been strongly flavored by its population and zoological emphases, and those of restoration have been flavored by its community and botanical emphases. Out of several strong candidates, I would suggest population dynamics and population viability as the core concepts in conservation biology (Norton, 1995; Beissinger and Westphal, 1998), and succession and assembly as the core concepts in restoration ecology (Luken, 1990; Packard, 1994; Hobbs and Norton, 1996; Lockwood, 1997; Pritchett, 1997).

On a more operational level, restoration projects are more likely to be grass-roots initiated or implemented by people living in the local community. Conservation projects, which are more likely to occur far from human settlement, are more often 'top-down' activities, initiated and implemented by government agencies and national or regional conservation organizations.

\section{The future of conservation and restoration}

Here is the means to end the great extinction spasm. The next century will, I believe, be the era of restoration in ecology

E.O. Wilson (1992)

While my previous observations are well supported by evidence from the literature, I now explore an aspect of restoration and conservation that is more speculative. I would like to suggest that within the next several decades, there will be a shift in emphasis in conservation science away from the topics central in current conservation biology toward an emphasis on ecological restoration. In short, that the long-term future of conservation biology is restoration ecology.

At the heart of this argument is the realization that we are in a unique biodiversity crisis. The core activities and paradigms of conservation biology are absolutely essential for the long-term conservation of biodiversity. I will address the possibility that this crisis is resulting from a temporary and devastating bottleneck, but it is clear that what we save will be dependent on the diameter of that bottleneck, and conservation is the main means we have for widening it. Ecological restoration offers the promise of shortening bottlenecks.

It is my belief that 50 years from now, the majority of the world's habitats and species will either be destroyed or on their way to recovery from a degraded state. When conservation biologists meet, they will be concerned less with how to conserve remnants of small populations and how to prevent further habitat degradation, and more with how to consolidate and restore the remnants of the crisis. Some are doing this even now.

What world trends lead me to suggest this change in emphasis? First, the down side: I believe that most of the biodiversity that will be lost to humans will be lost in the next fifty years. But I also believe that population stabilization, land abandonment, and biodiversity awareness provide a window of opportunity (Waggoner et al., 1996) for shaping a world in which future losses will not only become less likely in the latter half of the next century, but will begin to be reversed.

\subsection{Population stabilization}

For the first time since such statistics were kept, population growth rates are becoming less positive on all continents of the globe. The United Nations has been making global population projections for many years, 
and their recent 'most likely' projections are that world population will essentially stabilize by the middle of the 21 st century, to more than $90 \%$ of the eventual maximum world population. In March of 1998, they lowered their best guess of the maximum number from 11.5 billion to 10.8 billion, and then yet again in October of 1998 lowered the 2050 estimate by another half billion, based mostly on faster than expected reductions in birth rates (United Nations, 1998a,b). Most conservation biologists would reasonably argue that ten billion people is still far too many, and the rising economic expectations of these people is likely to present a far greater threat to the environment than just their numbers. Nonetheless, a stable or even (in many countries) declining population within the next century may allow the survival of considerable biodiversity. Forty percent of the world's population live in countries where natality is already below replacement, and some European countries are projected to decline in population appreciably in the next 50 years.

\subsection{Land abandonment}

Of equal or greater importance to biodiversity is where these billions are choosing to live. Thus far, the greatest biodiversity losses have occurred through habitat loss. Conversely, the greatest opportunities for ecological restoration occur through land abandonment. Worldwide, there is a continuing movement of people from rural areas to cities and suburbia (O'Meara, 1999). These cities are often environmental, employment, and logistical nightmares, but they do represent demographic abandonment of the land, especially lands of marginal agricultural value (e.g. Popper and Popper, 1994; Licht, 1997).

Demographic abandonment is often followed by land use abandonment, in which less productive land is taken out of production and allowed to revert to a (degraded) 'natural' state. A survey of Current Contents ${ }^{\circledR}$ in June 1998 revealed exponential growth in the numbers of research articles with the title words 'Land abandon\#' (Fig. 1b), and most of these articles were concerned with ecological restoration. A large number of restoration sites throughout North America and Europe are the results of agricultural abandonment.

The resurgence of regenerating temperate forests of the United States (and elsewhere) is perhaps the most dramatic example of land use abandonment (Williams, 1989; Wernick et al., 1997; Moffat, 1998), but this is increasingly a tropical phenomenon as well. The famous Biological Dynamics of Forest Fragments experiment in the Amazon has recently been plagued by the regeneration of (early successional) forest on abandoned land between the habitat islands (R. Bierregaard, pers. commun.). This is part of a worldwide trend in which the abandonment of tropical lands previously converted from forest to agriculture is occurring on a scale similar to and even exceeding deforestation itself (Houghton, 1994; Lamb et al., 1997). This is still happening, of course, in the context of catastrophic net losses of primary tropical forest habitat (Laurance and Bierregaard, 1997; Laurance, 1998).

In the semi-arid Laikipia ecosystem where I work in Kenya, decades of land subdivision and agricultural conversion are now being reversed, with land ownership consolidating and land use reverting to non-farming uses (livestock production and wildlife tourism). Although the world is likely to need vast areas of prime agricultural land for the foreseeable future (Brown, 1999), the dissemination of agricultural technologies that are increasingly efficient and environmentally sustainable may allow vast amounts of land under the plow to revert, even with modest population growth (Waggoner et al., 1996). The amount of land under the plow in the United States has declined throughout the 20th Century even as the population has more than doubled and food exports continue to exceed imports (Table 3 ). This abandoned land represents a golden opportunity for restoration ecology, and therefore for conservation (Dobson et al., 1997a,b).

The regenerating ecosystems on these abandoned lands do not replace the ecosystems that were lost, at least on the scale of many decades, and it would be far better to not lose the original habitats (Vitousek, 1994). It is becoming increasingly clear that much of this devastating habitat degradation, whether it is by subsistence farmers or by large logging or ranching concerns, contributes little to national economic development (Gullison and Lossos, 1993). The sooner we recognize both the minimal gains and the temporary nature of alternative land uses, the more likely we are to conserve these habitats intact (Young 1993).

Although there will continue to be abandonment of marginal agricultural land as people move to the cities, it is clear that riparian, wetland, and coastal ecosystems will feel the brunt of this demographic movement. These ecosystems will become increasingly threatened even as pressure on more terrestrial and inland ecosystems starts to ease.

\subsection{Biodiversity awareness}

We live in an age of unique biodiversity awareness. Conservative politicians call themselves 'green', entire

Table 3

Twentieth century patterns of population and land under cultivation in the United States (most values from United States Department of Commerce 1975, 1997; the 1997 'Acres in cropland' was calculated from USDA, 1998)

\begin{tabular}{lrrrl}
\hline Year & 1920 & 1950 & 1970 & 1997 \\
\hline Population $\left(\times 10^{6}\right)$ & 106 & 151 & 203 & 268 \\
Acres of cropland $\left(\times 10^{6}\right)$ & 413 & 409 & 384 & 356 \\
Acres cultivated per capita & 3.9 & 2.7 & 1.9 & 1.3 \\
Farm population $\left(\times 10^{6}\right)$ & 32 & 23 & 10 & $3.7(1995)$ \\
\hline
\end{tabular}


cable channels are dominated by nature programming, international boycotts and treaties enforce conservation practices, and young people worldwide understand both practical and esthetic values of biodiversity. Perhaps the most dramatic conservation trend in the latter half of the twentieth century has been the increase in sympathy for biodiversity that cuts across ages, political views, income levels, and levels of national development (Newmark et al., 1993; Young, 1993; Czech et al., 1998). Progress has not been monotonic, and some feel we are living in an era of retrenchment. (Certainly the trend of international conservation organizations being bought out by development dollars is not encouraging.) However, there is every reason to believe that aggressive education campaigns will continue to win the hearts and minds of increasing numbers in future generations. If we are to pass through the conservation bottleneck into the restoration era, we will need the broad-based support of these generations.

\subsection{Caveats}

Of course, the above analysis is simplistic as well as optimistic. We may yet destroy the world's biodiversity with global warming, ozone depletion, wasteful land use, and unbridled population and consumptive growth (Vitousek, 1994). Cities are no panacea. They must be made attractive, livable, efficient, and sustainable (Mangel et al., 1996; O’Meara, 1999). Modern methods of food production have not yet proven that they can be maintained in the long run, although the trends are encouraging (Waggoner et al., 1996; Rasmussen et al., 1998). I offer here not a definitive solution, but the outlines of a ray of hope for the future, a future in which ecological restoration can move to the fore.

Restoration may become the dominant conservation activity in the latter part of the coming century (and thereafter), but it will only be able to work with what we manage to salvage in the interim. Conservation biology and implementation as they are practised today are nothing less than the most important human activities in the history of the planet. It is my optimistic hope that one day they can take a back seat to the great restoration opportunities that are already being seized, and that will increase dramatically in the future. In addition, I believe that a restoration mind set can also enhance current conservation theory and practice.

\section{Implications of the differences between conservation and restoration, or how a restoration mind set can illuminate conservation biology}

Independent of my suggestion that ecological restoration will come to dominate conservation in coming decades, I would like to suggest that a restoration mind set can illuminate conservation research and policy even as they are practised today. The conservation mind set is one of more or less permanent loss; the implicit assumption is that all trends are down, and that our goal is to slow or stop degradation (declining population paradigm) or to maintain the remnants as small fragments of the original (small population paradigm). Delisting endangered species is met with (justified?) suspicion.

The restoration mind set is one of recovery after temporary loss. Conservation problems are viewed in the context of this future recovery. When restoration ecologists hear a statement like, 'This endangered population of 250 individuals has a $50 \%$ chance of extinction over the next 100 years', they think, 'Why would we let this population languish at 250 individuals for so long? Let's restore it!'

One may even say that restoration ecologists tend to be optimistic, and conservation biologists pessimistic. This has led to conflicting interpretation of trends (Richter, 1997; Dobson et al., 1997b). I would argue that both contain elements of truth.

The following are three specific examples of applying a restoration mind set in a conservation biology setting:

\subsection{Species recovery plans and captive breeding/gene banks}

In fact, several major activities of conservation biologists are fully in the restoration mind set. Reintroduction projects and research (Strum and Southwick, 1986; Stanley-Price, 1989; Kleiman et al., 1991; Bowles and Whelan, 1994; Ostro et al., 1999) are about single species restorations, although rarely coupled with an overall community restoration project (Falk et al., 1996). Although limited in species richness, captive breeding and gene bank programs often have as one of their main assumptions the future restoration of functional ecosystems.

\subsection{Edges and fragmentation}

One of the consequences of habitat fragmentation is increased edge-to-interior ratio, especially in the context of a mosaic of degraded and intact habitat (Fig. 2). Conservation biologists have richly documented the negative consequences of these edges (e.g., Alverson et al., 1994; Murcia, 1995; Wester and Young, 1997; Russo and Young, 1997; Viana et al., 1997; Hartley and Hunter, 1998; Stevens and Husband, 1998). In particular, edges favor weedy species at the expense of more specialized and often rarer interior species.

On the other hand, there is increasing evidence that habitat regeneration on degraded land is limited by distance to the nearest intact edge. Numerous studies have documented declines in woody plant recruitment or seed rain as one moves away from the edge of intact forest into surrounding degraded land (Gorchov et al., 1993; Robinson and Handel, 1993; Guariguata et al., 1995; 
a.
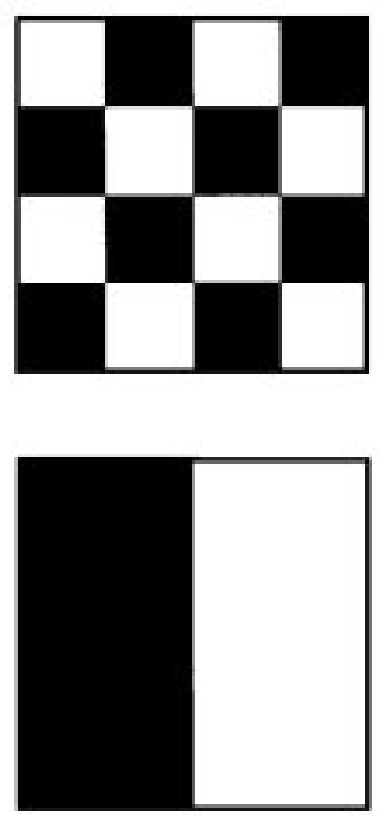

b.
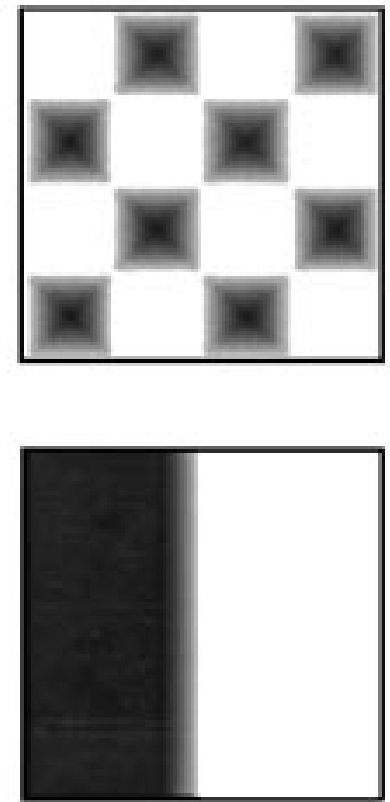

C.
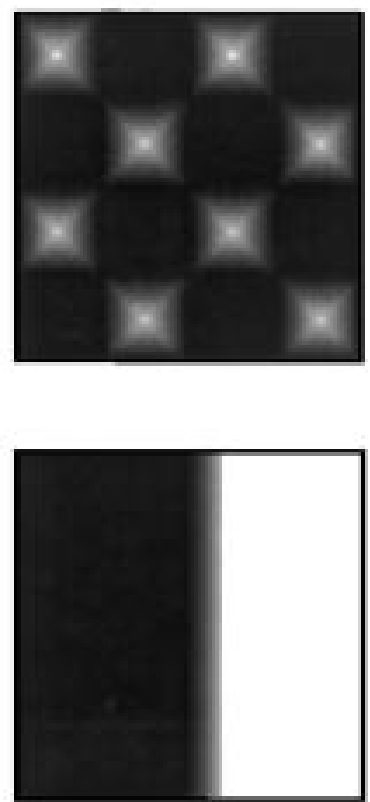

Fig. 2. The effects of different fragmentation patterns on an ecosystem. Dark areas represent healthy habitat, and light areas represent degraded habitat. (a) In both patterns half the original habitat is destroyed, leaving either small patches with high edge-to-interior ratios (top) or large patches with low edge-to-interior ratios (bottom). (b) Negative edge effects are more degradative when the habitat is broken into smaller fragments. Conservation biologists generally consider this scenario when recommending small edge to interior ratios. (c) Positive edge effects, such as the arrival of regeneration propagules, may be maximized in a degraded landscape with more embedded fragments.

Bakker et al., 1996; Wunderle, 1997; Keenan et al., 1997; Lamb et al., 1997; Parrotta et al., 1997; Clark et al., 1998). In addition, exposed canopy edges produce more seeds than shaded interior canopies (Young, 1995).

If we think of habitat fragmentations as essentially permanent (conservation biology mind set), then the negative aspects of high edge-to-interior dominate our thinking. If we think of these fragmentations as transitory (restoration ecology mind set), then the regenerative aspects of edge to interior ratio become a factor. Traditional landscape analysis in conservation recommends low edge-to-interior ratios, based on the negative influences of edge (Fig. 2b). Such analysis suggests that leaving a few large areas intact with most of their land far from degradative edges (Fig. 2b, below) is better than leaving many small areas with exposed edges (Fig. $2 \mathrm{~b}$, above). This analysis is particularly applicable in mosaics of protected reserves and (permanent) alternative land uses that are incompatible with biodiversity.

In a regenerating mosaic, however, increased edge potentially can confer a benefit, especially when edges are a critical source of regeneration propagules (Fig. 2c). In such situations, leaving many small areas intact and therefore leaving more degraded land near intact habitat (Fig. 2c, above; see Liu and Ashton, 1999) may be preferable to leaving a few large areas intact, but isolating much of the degraded habitat from sources of regenerative propagules (Fig. 2c, below; see also Davis and Cantlon, 1969).
Of course, this example is not intended as a full analysis of negative and positive aspects of fragmentation, of which edge effects are only a part (see Harris, 1984; Alverson et al., 1994; Laurence and Bierrregaard, 1997; Schwartz, 1997). Indeed, evidence suggests that uncritical application of the "checkerboard" pattern by the United States Forest Service in the past was more detrimental to old growth coniferous forests than it was beneficial to forest regeneration (Wallin, 1993). This example is offered instead to illustrate how a restoration mind set could, in the right circumstances, provide a new and potentially valuable tool in making land management decisions, and one that has not been fully examined as a research question in conservation biology.

\subsection{Rural development}

One of the keystones of modern biodiversity conservation in the tropics is the widespread uncritical acceptance of the concept of integrated conservation and development projects (ICDPs and their relatives). These projects have at their heart the untested assumption that economically assisting rural populations in the vicinity of biodiversity will enhance the viability of that biodiversity. Although some of these projects have been relatively successful as small scale economic development, there is little scientific evidence of their success as conservation projects (Kiss, 1998; Inamdar et al., 1999) other than via their enforcement and education components. In 
fact, there is increasing evidence that they may exacerbate threats to biodiversity by increasing population pressure in sensitive areas (Branden and Wells, 1992; Oates, 1995; Barrett and Arcese, 1995; Noss, 1997). More fundamentally, ICDPs are also based on the conservationist's mind set of fixed land losses and fixed demographic and land use patterns.

There are three human groups concerned about poor rural populations in biodiversity areas. Most of the slash and burn subsistence agriculturists themselves do not want to be there. They would rather have good jobs in the city. The governments may use these rural areas as population pressure valves, but in the long run would rather have the development of urban manufacturing and service industries that would fill the people's economic needs. Most conservationists (although a shrinking number of conservation organizations) clearly recognize that the ideal would be to have far fewer people in the rural landscape (Terborgh, 1989; Caro et al., 1998). Yet these three groups produce plans (ICDPs) that have as their main effects the delay or reversal of the movement off of the land that all three would prefer, and that would be the best conservation strategy of all. This is not strictly a tropical phenomenon. Similar government policies have similar retarding effects on land abandonment in the Great Plains of the United States (Licht, 1997), and in other agricultural ecosystems of Europe and North America.

I am not suggesting that we stop short-term rural development, but rather that we recognize the reality of demographic and land use abandonment, and work with rather than against this natural force. This is primarily a restorationist's mind set of temporary habitat loss. If we recognize that habitat losses to subsistence and marginal agriculture (and extractive industries) are temporary phenomena, we can work to increase the rate of the subsequent land abandonment (and to actively prevent losses in the first place) and to ensure that in the interim, local habitat losses are in the context of a mosaic of land use that maximizes the probability of successful natural regeneration and active restoration that will follow.

\section{Conclusion}

The divergent approaches documented here have impeded a fuller integration of biodiversity conservation and restoration. Perhaps by recognizing these differences explicitly, these two fields can take more conscious steps toward fruitful collaboration. The biodiversity crisis represents the greatest challenge humans have ever faced. To the extent that this generation will continue to fail, it will represent our greatest failure as a species, and the one for which we are least likely to be forgiven by the generations to come. To the extent that we at least partly succeed (in spite of ourselves), it will represent our species' greatest achievement. Conservation biology in the short-term and restoration ecology in the long-term are the complementary activities that will form the basis of our belated (but not hopeless) attempt to salvage the disaster.

\section{Acknowledgements}

While failures of fact and interpretation are entirely mine, this paper benefited from the assistance, insights, and comments of Mark Schwartz, Sharon Collinge, Marcel Rejmanek, Frank Popper, Russell Huddleston, Jaymee Marty, Tova Spector, Todd Palmer, Megan Lulow, and two anonymous reviewers.

\section{References}

Allen, E.B., Covington, W.W., Falk, D.A., 1997. Developing a conceptual basis for restoration ecology. Restoration Ecology 5, 275.

Allen, E.B., 1998. Response. Restoration Ecology 6, 134.

Alverson, W.S., Kuhlman, W., Waller, D.M., 1994. Wild Forests: Conservation Biology and Public Policy, Island Press, Washington, DC.

Bakker, J.P., Poschlod, P., Strykstra, R.J., Bekker, R.M., Thompson, K., 1996. Seed banks and seed dispersal: important topics in restoration ecology. Acta Botanica Neerlandica 45, 461-490.

Barrett, C.B., Arcese, P., 1995. Are integrated conservation-development projects (ICDPs) sustainable? On the conservation of large mammals in sub-Saharan Africa. World Development 23, 1073-1084.

Beissinger, S.R., Westphal, M.I., 1998. On the use of demographic models of population viability in endangered species management. Journal of Wildlife Management 62, 821-841.

Bowles, M.L., Whelan, C.J. (Eds.), 1994. Restoration of Endangered Species: Conceptual Issues, Planning, and Implementation. Cambridge University Press, New York.

Branden, K.E., Wells, M., 1992. Planning for people and parks: design dilemmas. World Development 20, 557-570.

Brown, L.R., 1999. Feeding nine billion. In: Starke, L. (Ed.), State of the World 1999. W.W. Norton and Company, New York, pp. 115-132.

Caro, T.M., Pelkey, N., Borner, M., 1998. Consequences of different forms of conservation for large mammals in Tanzania: preliminary analyses. African Journal of Ecology 36, 303-320.

Caughley, G., 1994. Directions in conservation biology. Journal of Animal Ecology 63, 215-244.

Clark, J.S., Macklin, E., Wood, L., 1998. Stages and spatial scales of recruitment limitation in southern Appalachian forests. Ecological Monographs 68, 213-235.

Czech, B., Krausman, P.R., Borkhataria, R., 1998. Social construction, political power, and the allocation of benefits to endangered species. Conservation Biology 12, 1103-1112.

Davis, R.M., Cantlon, J.E., 1969. Effect of size area open to colonizartion on species composition in early old-field succession. Bulletin of the Torrey Botanical Club 96, 660-673.

Dobson, A.P., Bradshaw, A.D., Baker, A.J.M., 1997a. Hopes for the future: restoration ecology and conservation biology. Science 277, 515-522.

Dobson, A.P., Bradshaw, A.D., Baker, A.J.M., 1997b. Restoring ecosystems - response. Science 278, 1000-1001.

Falk, D.A., Millar, C.I., Olwell, M. (Eds.), 1996. Restoring Diversity: Strategies for Reintroduction of Endangered Plants. Island Press, Washington, DC. 
Gorchov, D.L., Cornejo, F., Ascorra, C., Jaramillo, M., 1993. The role of seed dispersal in the natural regeneration of rain-forest after strip-cutting in the Peruvian Amazon. Vegetatio 108, 339349.

Guariguata, M.R., Rheingans, R., Montagnini, F., 1995. Early woody invasion under tree plantations in Costa Rica: implications for forest restoration. Restoration Ecology 3, 252-260.

Gullison, R.E., Lossos, E.C., 1993. The role of foreign debt in deforestation in Latin America. Conservation Biology 7, 140-147.

Harris, L.D., 1984. The Fragmented Forest. University of Chicago Press, Chicago.

Hartley, M.J., Hunter, M.L., 1998. A meta-analysis of forest cover, edge effects, and artificial nest predation rates. Conservation Biology $12,465-469$.

Hobbs, R.J., Norton, D.A., 1996. Towards a conceptual framework for restoration ecology. Restoration Ecology 4, 93-110.

Houghton, R.A., 1994. The worldwide extent of land-use change. Bioscience 44, 305-315.

Inamdar, A., de Jode, H., Lindsay, K., Cobb, S., 1999. Capitalizing on nature: protected area management. Science 283, 1856-1857.

Jordan, W.R., Gilpin, M.E., Aber, J.D., 1987. Restoration Ecology, Cambridge University Press, Cambridge.

Keenan, R., Lamb, D., Woldring, O., Irvine, T., Jensen, R., 1997. Restoration of plant biodiversity beneath tropical tree plantations in Northern Australia. Forest Ecology and Management 99, 117-131.

Kiss, A., 1998. Kenyan wildlife conservation. Science 281, 347.

Kleiman, D.G., Beck, B.B., Dietz, J.M., Dietz, L.A., 1991. Costs of a re-introduction and criteria for success: accounting and accountability in the golden lion tamarin conservation program. Symposia of the Zoological Society of London 62, 125-142.

Lamb, D., Parrotta, J., Keenan, R., Tucker, N., 1997. Rejoining habitat fragments: restoring degraded rainforest lands. In: Laurance, W.F., Bierregaard, R.O. (Eds.), Tropical Forest Remnants: Ecology, Management, and Conservation of Fragmented Communities. University of Chicago Press, Chicago, pp. 366-385.

Laurance, W.F., 1998. A crisis in the making: responses of Amazonian forests to land use and climate change. Trends in Ecology and Evolution 13, 411-416.

Laurance, W.F., Bierregaard, R.O. (Eds.), 1997. Tropical Forest Remnants: Ecology, Management, and Conservation of Fragmented Communities. University of Chicago Press, Chicago.

Licht, D.S., 1997. Ecology and Economics of the Great Plains. University of Nebraska Press, Lincoln.

Liu, J., Ashton, P.S., 1999. Simulating effects of landscape context and timber harvest on tree species diversity. Ecological Applications 9, 186-201.

Lockwood, J.L., 1997. An alternative to succession: assembly rules offer guide to restoration efforts. Restoration and Management Notes $15,45-50$.

Lugo, A., 1998. Tropical restoration for the new millennium. SER (Society for Ecological Restoration) News 11(2), 1, 10-11.

Luken, J.O., 1990. Directing Ecological Succession. Chapman and Hall, New York.

Mangel, M. et al. (40 co-authors), 1996. Conservation of wild living resources. Ecological Applications 6, 338-362.

Michener, W.K., 1997. Quantitatively evaluating restoration experiments: research design, statistical analysis, and data management considerations. Restoration and Management Notes 5, 324-337.

Moffatt, A.S., 1998. Temperate forests gain ground. Science 282, 1253.

Morrison, M.L., 1995. Wildlife conservation and restoration ecology: toward a new synthesis. Restoration and Management Notes 13, 203-208.

Morrison, M.L., 1998. Letter to the editor. Restoration Ecology 6, 133.

Murcia, C., 1995. Edge effects in fragmented forests - implications for conservation. Trends in Ecology and Evolution 10, 58-62.

Neal, P.R., 1998. Pollinator restoration. Trends in Ecology and Evolution 13, 132-133.
Newmark, W.D., Leonard, N.L., Sariko, H.I., Gamassa, D.M., 1993. Conservation attitudes of local people living adjacent to five protected areas in Tanzania. Environmental Conservation 19, 17123.

Norton, T.W., 1995. Special Issue-Applications of population viability analysis to biodiversity conservation-Introduction. Biological Conservation 73, 91 .

Noss, A.J., 1997. Challenges to nature conservation with community development in central African forests. Oryx 31, 180-188.

Oates, J.F., 1995. The dangers of conservation by rural developmenta case study from the forests of Nigeria. Oryx 29, 115-122.

O’Meara, M., 1999. Exploring a new vision for cities. In: Starke, L. (Ed.), State of the World 1999. W.W. Norton and Company, New York, pp. 133-150.

Ostro, L.E.T., Silver, S.C., Koontz, F.W., Young, T.P., Horwich, R., 1999. Ranging behavior of translocated and established groups of black howler monkeys (Alouatta pigra) in Belize, Central America. Biological Conservation 87, 181-190.

Packard, S., 1994. Successional restoration: thinking like a prairie. Restoration and Management Notes 12, 32-39.

Parrotta, J.A., Knowles, H.K., Wunderle, J.M., 1997. Development of floristic diversity in 10-year-old restoration forests on a bauxite mine in Amazonia. Forest Ecology and Management 99, 21-42.

Parrotta, J.A., Turnbull, J.W. (Eds.), 1997. Catalyzing native forest regeneration on degraded tropical lands. Forest Ecology and Management 99, 1-290.

Popper, D., Popper, F., 1994. The Great Plains: checkered past, hopeful future. Forum for Applied Research and Public Policy 9, 89-100.

Pritchett, D.A., 1997. Maybe, sometimes: a practitioner replies. Restoration and Management Notes 15, 51.

Quammen, D., 1996. The Song of the Dodo: Island Biogeography in an Age of Extinctions. Scribner Island Press, New York.

Rasmussen, P.E., Goulding, K.T., Brown, J.R., Grace, P.R., Janzen, H.H., Korschens, M., 1998. Long-term agroecosystem experiments: assessing sutainability and global change. Science 282, 893-896.

Richter, W., 1997. Restoring ecosystems. Science 278, 997-998.

Robinson, G.R., Handel, S.N., 1992. Forest restoration on a closed landfill: rapid addition of new species by bird dispersal. Conservation Biology 7, 271-278.

Russo, C., Young, T.P., 1997. Egg and seed removal at urban and suburban forest edges. Urban Ecosystems 1, 171-178.

Schwartz, M.W. (Ed.), 1997. Conservation in Highly Fragmented Landscapes. Chapman and Hall, New York.

Soule, M.E. (Ed.), 1986. Conservation Biology. Sinauer, Sunderland, MA.

Stanley-Price, M.R., 1989. Animal Re-introductions: The Arabian Oryx in Oman. Cambridge University Press, Cambridge.

Stevens, S.M., Husband, T.P., 1998. The influence of edge on small mammals: evidence from Brazilian Atlantic forest fragments. Biological Conservation 85, 1-8.

Strum, S.C., Southwick, C.H., 1986. Translocation of primates. In: Benirschke, K. (Ed.), Primates: the road to self-sustaining populations. Springer-Verlag, New York, pp. 949-957.

Terborgh, J., 1989. Where Have all the Birds Gone? Princeton University Press, Princeton, New Jersey.

United Nations, 1998a. World population projections to 2150. United Nations Department of Economic and Social Affairs (Population Division), New York.

United Nations, 1998b. World population estimates and projections. United Nations Department of Economic and Social Affairs (Population Division), New York.

United States Department of Commerce, 1975, 1997. Statistical abstract of the United States. Washington, DC.

United States Department of Agriculture, 1998. National Agricultural Statistics Survey: Acreage. Washington, DC.

Viana, V.M., Tabanez, A.A.J., Batista, J.L., 1997. Dynamics and restoration of forest fragments in the Brazilian Atlantic moist forest. 
In: Laurance, W.F., Bierregaard, R.O. (Eds.), Tropical Forest Remnants: Ecology, Management, and Conservation of Fragmented Communities. University of Chicago Press, Chicago, pp. 351-365.

Vitousek, P.M., 1994. Beyond global warming: ecology and global change. Ecology 17, 1861-1876.

Waggoner, P.E., Ausubel, J.H., Wernick, I.K., 1996. Lightening the tread of population on the land: American examples. Population and Development Review 22, 531-545.

Wallin, D.O., Swanson, F.J., Marks, B., 1993. Landscape pattern response to changes in pattern generation rules - land-use legacies in forestry. Ecological Applications 4, 569-580.

Wernick, I.K., Waggoner, P.E., Ausubel, J.H., 1997. Searching for leverage to conserve forests: the industrial ecology of wood products in the U.S. Journal of Industrial Ecology 1, 125-145.

Wester, A., Young, T.P., 1997. Spatial pattern of deer herbivory at suburban forest edges. Restoration and Management Notes 15, 186-187.
Williams, M., 1989. Americans and Their Forests. Cambridge University Press, Cambridge, United Kingdom.

Wilson, E.O., 1992. Diversity of life, Harvard University Press, Cambridge, MA (p. 340).

With, K.A., 1997. The theory of conservation biology. Conservation Biology 11, 1436-1440.

Wunderle, J.M., 1997. The role of animal seed dispersal in accelerating native forest regeneration on degraded tropical lands. Forest Ecology and Management 99, 223-235.

Young, T.P., 1993. Development and conservation: more on caring. Conservation Biology 7, 750-751.

Young, T.P., 1995. Landscape mosaics created by canopy gaps, forest edges, and bushland glades. Selbyana 16, 127-134.

Zedler, J.B., 1996a. Ecological issues in wetland mitigation - an introduction to the forum. Ecological Applications 6, 33-37.

Zedler, J.B., 1996b. Coastal mitigation in southern California-the need for a regional restoration strategy. Ecological Applications 6, 84-93. 